\title{
NARRATIVE, NATURALISM AND THE BODY IN CLASSICAL GREEK AND EARLY IMPERIAL CHINESE ART
}

\section{INTRODUCTION}

For a historian of Greek art coming to the modern historiography of Chinese art for the first time, one of its most striking and surprising characteristics is the extraordinarily close parallelism between the terms we use to describe the transition between archaic and classical Greek art, and those used by historians of Chinese art to describe artistic change from the Warring States to the Early Imperial Period. Lucy Lim, for example, describes the images of early Chinese pictorial vessels as being 'formal' and 'conventionalised', entailing a view of the world which is 'conceptual rather than perceptual' (figure 1). Changes in pictorial style during the later Warring States period are described in terms of advancing sophistication in the achievement of pictorial effects, in particular 'the realization of space and improvement in the handling of active human groups'. This culminates in a decisive breakthrough in the Western or Former Han (206 BC - AD 8), which saw 'a change from conceptual representations of the human figure to representations of corporeal images

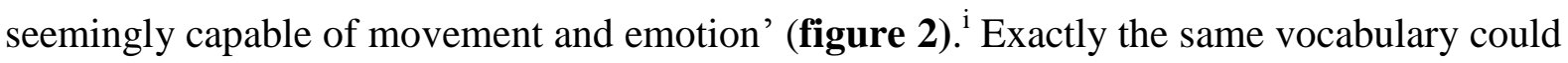
be - and has been - used to describe the earliest examples in Greek figurative representation, Attic geometric funerary vessels of the eighth century BC, the gradual transformation of figurative representation in the archaic period, and the break through to what we characterise as naturalism in the early classical period, in the first half of the fifth century BC (figures 34). ${ }^{\text {ii }}$ The parallel between the two processes of development is drawn most strikingly in the work of Wen Fong, who describes the evolution of Chinese figural representation during the early empire 'from rigid archaic 'frontality' to increasing naturalism' as the 'Han Tang miracle', echoing Ernst Gombrich's 'Greek miracle'.iii

For both classical art historians and historians of early Chinese art this apparent parallelism raises some interesting questions. One might, of course, argue that this parallelism is merely an artefact of western art historical vocabulary, ${ }^{\text {iv }}$ an issue to which I will return in due course. But if the parallelism between the Chinese and the Greek cases is real, and independent, ${ }^{\mathrm{v}}$ this has important implications for the two of the most important accounts of the development and character of 'naturalism' in Greek and more broadly western art, namely Ernst Gombrich's analysis of the so-called 'Greek Revolution' and Norman Bryson's alternative account of naturalism in his Vision and the Gaze. 
According to Gombrich, all art entails a process of making images and matching them against reality. Making presupposes some kind of schema, the conceptual image which Lim refers to, and which constitutes the minimal visual formula which suffices for an image to be recognised as a depiction of, for example, a human being or a horse. In traditional civilizations, such processes proceed at a very slow pace, and the correcting of schemata to match reality occurs only in a very limited degree. The extraordinary pace of the process in ancient Greece, and its scope with the development of full blooded illusionism, could only be explained, according to Gombrich, by two factors unique to the Greek tradition. First, Homeric narrative encouraged an interest in narrating 'not only what happened but how it happened', in contrast to Near Eastern and Egyptian narrative traditions. Second, democratic Athens was an open society, and as such encouraged the kind of incessant experimentation involved in the testing of artistic schemata against reality, and their progressive correction to match it. ${ }^{\text {vi }}$

Norman Bryson's Vision and Painting is perhaps the most sustained critique of the theoretical assumptions that inform Gombrich's account of naturalism. Invoking the linguistic turn in the cultural sciences, and in particular Saussure's structuralism, Bryson argued that artists and viewers do not have the unmediated access to 'reality' which is presupposed by Gombrich's account of making and matching, schema and correction. On the contrary, our experience of the world is always culturally mediated, a construct of the specific traditions of language and representation into which we are born. The 'effect of the real' which we experience when viewing the art of classical Greece and the Italian Renaissance is a result of an interaction between two levels of the sign. The denotative or iconographic code, which permits us to recognise the visual depiction of a myth or a bible story, is confirmed and substantiated by the addition of all kinds of culturally specific 'connotative' codes, of dress and gesture, for example, to the extent that picture appears to 'rise to a level of truth'. This 'confirms the natural attitude' according to which the meaning of a painting 'is felt to inhere within an objective world and is not apprehended as the product of a particular cultural work' ${ }^{\text {vii }}$ Of course these connotative codes vary, like languages, from cultural tradition to cultural tradition, so what we recognise as naturalistic is simply the set of cultural conventions with which we are familiar by virtue of upbringing and aesthetic education. ${ }^{\text {viii }}$

The apparent parallelism in the development of naturalism in early Greece and China is problematic for both Gombrich's and Bryson's accounts. If, following Bryson, the depictive strategies which we call naturalism constitute a set of culturally specific purely 
Western conventions which we have arbitrarily designated as representing the real, how can we explain the fact that many of the same depictive conventions seem to have developed independently in China? Does it not seem to imply that these depictive strategies may be not arbitrary conventions but, as Gombrich might suggest, somehow grounded in universal features of human perception? Conversely, for Gombrich, if it is only the special character of Homeric narrative, and the open character of democratic Greek politics, which explains the development of naturalism in the Greek world, how can we make sense of an apparently similar process of artistic development in early China, in the absence of any tradition of epic poetry, and at the same time as an autocratic state unified under a single emperor was being established, by no stretch of the imagination a democracy?

Historians of Chinese art have broadly had two responses to this supposed parallelism, both, in different ways, responses to the perception of the history of Greek art, and its Italian Renaissance successors, as a kind of normative model for art history in general. Some second generation Western scholars of Chinese art saw nothing particularly problematic or remarkable about the parallelism. As Alexander Soper remarked on the development of naturalism in Chinese art: 'There is nothing surprising in this process; western precedent has prepared us for the classically happy conclusion'. ix Increasingly, however, this broad evolutionary model of the development of Chinese art was subject to criticism, in the context of quite fierce debates on the status of Chinese art history as a discipline, situated uneasily between philologically oriented sinology and a discipline of art history dominated by theories and models developed for the study of Greco-Roman and Italian Renaissance art. ${ }^{\mathrm{x}}$ Unsurprisingly, there soon developed some doubt about using the Renaissance norm of naturalism to interpret a tradition of art in which it is a critical commonplace to remark that it is a sign of vulgarity and naivety to evaluate art in terms of its representational qualities at the expense of consideration of brushwork, so central to calligraphy, the most prized medium of aesthetic expression in the Chinese art. ${ }^{\mathrm{xi}}$ Further, as the chronology of Han art became more securely established, it emerged that the rather flat-looking engravings of the $\mathrm{Wu}$ Liang shrine which scholars like Soper had attributed to the archaic phase of their developmental scheme were actually later than those of , for example, the Zhu Wei shrine with its relatively sophisticated development of perspective. xii Subsequent studies have emphasized understanding these Han monuments in their own terms, through detailed contextual analysis of iconographic and stylistic programmes. Wu Hung, for example, has explored the iconography of the Wu Liang shrine against the background of concepts of time and history 
developed in the Records of the Historian by Sima Qian. ${ }^{\text {xii }}$ Martin Powers has sought to account for the style pluralism of the Han through an exploration of the rhetorical strategies of different social groups, arguing that the archaism of the $\mathrm{Wu}$ Liang shrine represents a specifically Confucian aesthetic of simplicity which implicitly criticised the richer more descriptive styles sponsored by merchants and eunuchs. ${ }^{\text {xiv }}$

This contextual turn has certainly enhanced our understanding of early imperial Chinese art, and it betrays an affinity with a similar paradigm shift within the field of art history more generally, which saw a turning away from longer term grand narratives of stylistic change and development. There are, however, some unresolved anomalies. First, it is dangerous to extend the scorn for an aesthetics of resemblance expressed in some Chinese painting theory beyond the specific historical and class context in which it was expressed and became dominant, namely the tradition of amateur literati painters distancing themselves from their professional counterparts, above all in the Song Dynasty and after. ${ }^{\mathrm{xv}}$ There is in fact plenty of evidence for an interest in an aesthetics of illusion in early imperial Chinese art comparable with that of classical Greece. Take the story of the Greek painter Zeuxis, who painted grapes with such verisimilitude that they enticed birds to peck at his painting, or Parhassios who painted a curtain over that painting so realistic that it deceived even Zeuxis who demanded that the curtain be drawn back to reveal his masterpiece. There are similar anecdotes in the histories of early imperial Chinese art, for example concerning two third century painters. One, Xu Mo, painted a fish so realistic that, when hung at the shore of a lake, all the resident otters 'came racing to the spot' and were consequently easily captured. Another, Cao Bu Xing, whilst painting a scroll accidentally let a drop of ink fall from his brush onto the silk; unable of course to erase it, he added a few details to transform the blotch into a fly, achieving such a level of realism that the emperor, on opening the scroll, tried to brush the fly off it. ${ }^{\text {xi }}$ Second, whilst Martin Powers is surely correct to see the many aspects of the style of the pictures of the Wu Liang shrine as deliberately archaising, it is worth noting that they nevertheless retain certain features of what Lucy Lim recognised as the naturalistic advances of the early Han, rather than reverting to the conceptual style of the earlier pictorial bronzes. These naturalistic elements include a repertoire of expressive gesture, the coordination of figures into dialogic interaction, and surprisingly often figure schemes which imply a pictorial depth which cuts against the grain of the archaising flatness of the images, as in the core group from this depiction of the story of Min Ziqian's filial piety, with Min Ziqian seen in a strongly foreshortened three-quarter back view (figure 5). ${ }^{\text {xvii }}$ That is to 
say, the style of the Wu Liang shrine, like the descriptive and ornamental styles of the merchants and eunuchs, all presuppose and in varying ways draw upon the development of naturalism during the first three centuries of the Han, and that broader development is left unexplained by Powers's approach, as also by the iconographic approach of Wu Hung.

It is against the background of these interpretive anomalies that Wen Fong has recently revived the case for seeing a strong parallelism between the developments in classical Greece and their counterparts in China, echoing Gombrich's 'Greek Revolution' with what he calls 'The Han-Tang Revolution'. Fong argues that Gombrich's account of making and matching, schema and correction can equally be applied to the development of Chinese art from the late Warring States to the Tang, but argues that the Chinese master representation in their own terms, specifically terms derived from calligraphy. ${ }^{\text {xvii }}$ There are certain aspects of this argument which are quite attractive, particularly in explaining the different trajectories of late classical Greek (fourth century BC) and Six Dynasties and later (fourth century AD) Chinese art. But at least as it stands, Fong's argument will not do as an account of the development of painting in the Han, with which we are concerned here. First, Gombrich's account of making and matching presupposes direct perceptual access to an unmediated natural reality against which to test, and then correct, representations: it makes no sense to think of making and matching in Chinese terms as opposed to Western terms. Second, even if calligraphic theory does, ultimately, play an important role in Chinese painting theory, it cannot explain the development of naturalism in the Han, since the earliest evidence for such calligraphic theory is late second century $\mathrm{AD}$, at least two centuries after the emergence of naturalism in Han figurative art and the first manifestations of any influence of calligraphy theory on painting theory are still later. ${ }^{\text {xix }}$

My purpose in this article is to develop a first sketch of a more systematic comparative analysis of classical Greek and Han Chinese naturalism, and to show how such a comparative approach can resolve some of the conundrums thrown up by the casual and implicit east-west comparisons of earlier studies. I hope to show that a comparative approach both requires and facilitates the development of a more sophisticated understanding of exactly what naturalism might be, and that it permits a more persuasive account of the perceptual, social, political and cultural coordinates of the artistic phenomena we categorise as 'naturalism' in classical Greece and early imperial China. 
My approach is informed by the phenomenological art history of David Summers, the pragmatist philosophy of Mark Johnson, and the cultural sociology of Robert Witkin. All three converge, from slightly different directions, on an approach to the body, and its artistic representation, which transcends the radical distinctions often drawn between the social, the cultural and the natural, instead exploring the interactions between these three dimensions of human being. David Summers has emphasised the importance of common 'physical human presence', and fundamental structures of embodiment, as a shared framework to which all human art making is oriented, and hence as a point of reference for a comparative art history 'able to address many traditions of art, and to bring the strands of their various accomplishments into significant relations of similarity and difference'. ${ }^{\mathrm{x}}$ Mark Johnson, integrating philosophy in the pragmatist tradition of Peirce and Dewey with recent work in neuropsychology, emphasises the continuity between biological, social and cultural life. Rather than reducing the cultural to the social, or the social to the biological, or conversely seeing culture as radically free-floating, as in traditions of thought influenced by structuralism (like Norman Bryson's account of naturalism), Johnson argues that cultural and social levels are emergent from, and rest upon, biological and specifically bodily foundations. In particular Johnson draws attention to the ways in even quite abstract ideas - a family tornapart, to grasp an argument - are often built metaphorically on embodied modes of engagement with the world, and that the abstract concepts can, in their turn, through the mechanism of mirror-neurons, evoke the original underlying bodily sensorimotor responses. $^{\text {xxi }}$

The work of Robert Witkin, in its turn, seeks to understand how the ways in which naturally given human perceptual capacities are variably appropriated in artistic culture according to a broadly evolutionary scheme of the development of social complexity, thus introducing an historical dimension to the explorations of the relationships between embodied human nature and cultures of artistic expression addressed in the work of Summers and Johnson. Building on Riegl's formal grammar of style, updated in terms of the perceptual psychology of J.J. Gibson and Piaget's developmental psychology, Witkin has sought to demonstrate an internal relationship between the stylistic organisation of action spaces figured in art works and dominant principles of social ordering characteristic of the societies in which such art works were produced. Summarising a rather complex argument, to which we will return in the conclusion, Witkin argues that there is an affinity between the development of naturalism, or what he refers to as 'perceptual realism', and social 
differentiation. In pre-urban societies, economic production is predominantly embedded in nature. Given the limited division of labour, ritual 'coaction' is the dominant principle of social action, and the language of art is 'invocational', emphasizing the signifier: individual figures are complete and self-contained in the values they signify, like the 'conceptual' figures of the bronzes depicting rituals (cf. figure 1), discussed by Lucy Lim, or early Greek traditions of figurative representation (cf. figure 2). In urban societies, production is increasingly disembedded from nature, interaction on the basis of the mutual interdependence entailed by a division of labour is the primary form of social action, the language of art is 'evocational', emphasising the signified, and the value of figure representations defined in terms of their relations to each other as they interact in a mimetically real optical space exemplified by Renaissance art. ${ }^{x i i}$ Witkin's exposition of his framework considers only the history of Western art from Egypt to twentieth century France, via the Italian Renaissance, although he does mention the case of ancient Greece as partially anticipating the transformations of the Renaissance. As such, Witkin's argument looks like a (sophisticated) sociological reprising of what Podro has called 'the critical tradition in art history', based on Hegel. The implicit burden of my argument is to suggest that whilst Witkin's broadly evolutionary model is quite fruitful, the common sociological transformations, which we will of course specify in more detail in the Greek and Chinese cases, are cut across by distinctive cultural traditions which give a specific inflection to the 'physiognomic naturalism' of classical Greece and early imperial China, notwithstanding their family resemblances.

Accordingly, for each tradition I will address three levels of analysis. First, I show the appropriation in Chinese and Greek art of certain natural affordances of the body - above all the gaze and expressive gesture - in the context of visual depiction of narratives. Second, I shall analyse the cultural frames in terms of which such depictive practices were responded to, and how shared depictive practices were overwritten or differentially elaborated in each of the two traditions according to culturally specific conceptions of the character and significance of living bodies in action. Third, I shall explore the social contexts in which narrative art was appropriated by viewers, and its implicit visual significances discursively elaborated, in order to place the development of naturalism in narrative art in its specific institutional and historical contexts in classical Greece and early imperial China. 


\section{GREEK NARRATIVES}

For the Greek case my primary focus will be on a group of paintings from the first half of the fifth century BC, particularly associated with the painter Polygnotos and a circle of painters around him who were responsible for major programmes of wall painting at Delphi and in the Athenian agora. Pausanias' description of Polygnotos' paintings in the Lesche of the Knidians at Delphi calls attention to two specific features of the painting of this period which seem to have enriched the depiction of interaction, namely the development of modes of facial expression which imply thought and reflection, and a rich vocabulary of expressive gesture. He describes some of the figures from a painting of the sack of Troy and its aftermath as follows 'Beyond Helen, a man wrapped in a purple cloak is sitting in an attitude

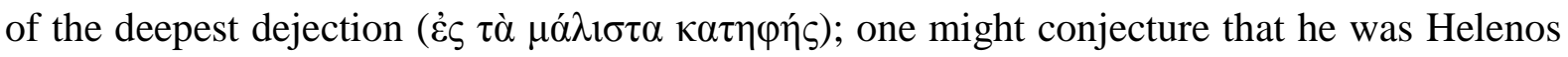
the son of Priam even before reading the inscription' (10.25.5); of the family of Antenor we are told 'The look on all of their faces is that of a people on who a great calamity had fallen -

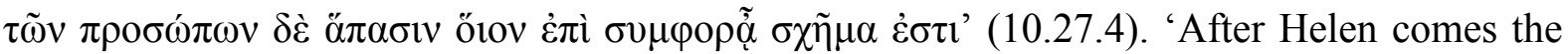
mother of Theseus with her hair shorn, and Demophon, one of the sons of Theseus, who, I gather from his attitude ( $\dot{\alpha} \pi$ ò $\tau o \tilde{v} \sigma \chi \eta ́ \mu \alpha \tau o \varsigma)$ is trying to determine whether it will be possible for him to save Aithra' (10.25.7). In his description of Odysseus visit to the Underworld, Pausanias draws attention to similar figures characterised in terms of expressive gestures: 'Seated near Pelias is Thamyris whose eyes have been blinded and is represented in the attitude of one who is completely humiliated ( $\tau \alpha \pi \varepsilon v v o ̀ v ~ \varepsilon ́ \varsigma ~ \alpha ँ \pi \alpha \nu ~ \sigma \chi \tilde{\eta} \mu \alpha)$ ' (10.30.8). 'In the lower part of the painting, Hector is seated, clasping his left knee with both hands, and represented in the attitude of one who grieves ( $\dot{\alpha} v 1 \omega \mu \varepsilon \dot{v} v o v \sigma \chi \tilde{\eta} \mu \alpha \dot{\varepsilon} \mu \varphi \alpha i v \omega v)$. After him comes Memnon.. Sarpedon buries his face in both hands, while Memnon places one hand on Sarpedon's shoulder' (10.31.5) 'Penthesilea is also there looking at Paris; she seems by the toss of her head to look at him with disdain and to treat him as of no account' (10.31.8). Further passages describe Theseus and Perithous looking 'angrily' at swords, and Protesilaos with his gaze fixed on Achilles (10.29.9; 10.30.3).

This interest in facial expression, gaze orientation and expressive gesture is particularly marked in a series of early classical vase-paintings that have been linked to Polygnotan painting, even to the extent that there may be grounds for supposing them to be loosely based on or copied after paintings done by Polygnotos and members of his circle. The best known is the reverse side of the Niobid Painter's name- vase (figure 6a), possibly 
showing Theseus and Perithous imprisoned in the underworld, after their attempt to abduct Persephone, possibly the assembly of gods and heroes prior to the battle of Marathon, themes painted in the Stoa Poikile and the Theseion at Athens. ${ }^{x x i i}$ For my purposes here, the specific narrative is not so important as the use of the three-quarter faces and profile eyes and directed gaze to organize quite complex sets of relationships between the different figures, as brought out in Jeppesen's diagram (figure 6b). This instance represents a relatively early stage in a development which was taken much further in classical art, where the organisation of the direction of the gazes of participants is regularly used to articulate the character of their relationship: the divergent glances of Achilles, Patroklos and Briseis in a painting from Pompeii, probably after a late classical prototype, suggests the fracturing of their relationships as Briseis prepares to depart for the tent of Agamemnon who has claimed her as his prize. ${ }^{\text {xxiv }}$

The development of three quarter representations of the face, and the increasing complexity of the organisation of gaze amongst participants in scenes, has profound consequences for the character of viewers' engagements with such narratives. As George Hanfmann, drawing the contrast between classical and archaic narratives, has put it: 'No matter how animated and agile archaic heroes may be, they do not appear to move by their own will. Their gestures are explanatory formulae imposed on the actors from without in order to explain what sort of action is going on... The curiously detached character of the archaic eye [depicted frontally within a profile face] .. shows that a person is alive but cannot adjust itself to the demands of a specific situation' (figure 7). ${ }^{\mathrm{xxv}}$ The effect of this transformation of the structure of the gaze within pictures is by no means arbitrary. On the contrary, there is good ethological research which suggests that sensitivity to the gaze is an evolutionary adaptation which plays a central role in articulating 'social cohesion and dominance hierarchies' amongst all primates, including humans. Shame and embarrassment are regularly signalled by withdrawal of one party from mutual gaze, and a third party observing the mutual gaze of two others will normally take it as an index of their interaction. ${ }^{\text {xxvi }}$ To be sure, the precise rules about who may hold gaze with whom for how long vary cross culturally, but for the purposes of my argument what is important is simply that this visual channel becomes available in classical art for articulating relationships within scenes of narrative interaction, and for inflecting viewers responses to such interactions. 
The gestural repertoire elaborated in early classical art seems also, at least in certain dimensions, to draw upon transparent signifiers of emotional expression, though as we shall see many also have a more culturally specific character. It is not very difficult to read the gestures of the women seated behind the statue in the Kleophrades Painter's sack of Troy as expressions of grief or pain (figure 8a-b), the female figures in a scene showing the abduction of Thetis by Peleus as manifesting alarm and astonishment (figure 9) or Penelope, at her loom, in the name-vase of the Penelope Painter (figure 10), as pensive. ${ }^{x v i i}$ The natural basis of this gestural language is indicated by its recycling in Renaissance art, Warburg's famous pathos-symbols, ${ }^{\text {xxviii }}$ and also by the remarkable stability of some of these visual types when transmitted into other cultural traditions - the Pensive Penelope, for example, becomes the Pensant Boddhisattva in East Asian Buddhist art (figure 11), though that particular SinoHellenic story will have to wait proper analysis in another context ${ }^{\text {xxix }}$

But we should not follow Gombrich and see this as entailing a liberation from schemata; on the contrary, the development of this language of gaze and gesture entailed the artistic coining of new schemata, but schemata which were grounded in certain universal potentialities of human sensory-motor function and expressive behaviour, according to the kinds of embodied metaphorical logics identified by David Summers and Mark Johnson, and clearly at work in Pausanias' reading of the gestural language of Polygnotos' paintings. Coining such schemata was, of course, a cultural skill, not least since it entailed codifying what in real life may have been fluid or momentary gestures into a fixed form with immediate visual impact and maximal communicative coherence. ${ }^{\mathrm{xx}}$ This skill was highly valued in the classical period, particularly in so far as it permitted the representation of character, or ethos. Polygnotus was especially esteemed for his precision in the use of schemata to communicate ethos and pathos. ${ }^{\mathrm{xxx}}$ Coining schemata, was not, of course restricted to painting and sculpture, but was characteristic of all the mimetic arts which had a visual dimension. Aischylos, for example, was famed for having characters on stage who spoke no words, but sat in a specific schema which communicated sorrow or some other emotion. He was also known to formulate the schemata for the choric dances in his tragedies, in addition to writing the plays. $^{\text {xxxii }}$

The development of these new depictive strategies was associated with new concepts of representation, and new expectations about viewing and responding to narrative art in sculpture and painting. 'Schema' was one of these concepts, at least in its usage to refer to 
codifications of gestural repertoire, but ethos was another, alongside pathos, mimesis and rhythmos, and these concepts require some exploration in order to understand both how these new visual formulae articulated with contemporary cultural discourses, and also how they relate to a particular social institutionalisation of art characteristic of the Athenian state in the classical period. In the Poetics, Aristotle comments that dancers imitate (mimountai) all kinds of actions (praxeis), characters (ethe) and emotions (pathe) by means of choreographed movements (schematizomenon rhythmon). ${ }^{\text {xxxiii }}$ Although here Aristotle refers specifically to dance, the vocabulary that he invokes was applied in the context of all the mimetic arts, including drama, sculpture and painting.

The concept of rhythmos is closely linked to that of schema to the extent that they can almost be interchangeable. ${ }^{\text {xxiv }}$ But the primary reference of rhythmos was to dance, specifically to the regularised ordering of movement in dance, particularly choric dance where the movement of multiple dancers needed to be coordinated with each other, the music and the metre of the poetry. Rhythmoi were the patterns or positions bodies were made to assume in the course of a dance, distinct intervals conceptualised not in terms of flow but in terms of the stops which bounded or marked out the structure of a complex pattern of movement. The transition from one rhythmic figure to the next was conceptualised as being instantaneous, and the stops as it were signified the entire movement. ${ }^{\mathrm{xxv}}$ It is this concept of rhythmos which informs the at once dynamic and statuesque character of Greek figurative art, whether sculpture or vase painting.

The counterpoint to the stops, which makes them dynamic rather than merely frozen, is the extraordinarily articulated character of the treatment of musculature in Greek art, and the implications of effort and movement implied by the tensioning represented therein. ${ }^{\text {xxvi }}$ Strictly speaking, as Shigehisa Kuriyama has argued, classical Greeks did not perceive muscles - a concept developed only by Galen. Rather they saw a complex set of relations between flesh (sarx) and sinews (neuroi) which served to articulate the surface and visible structures of the body. ${ }^{\text {xxvii }}$ Sinews and body tone seem to have been a shared preoccupation of medical writers, artists and physiognomists, all concerned, from disciplinarily specific angles but with a shared vocabulary, to understand the character of the Greek male body. Hippocratic writers describe the contraction and extension of sinews and muscles in movement, and the proper positioning of limbs for bandaging in cases of fracture, if such movement is not to disturb the dressings and undermine the therapy. ${ }^{\mathrm{xx} x v i i}$ Xenophon, in the 
Memorabilia, describes Socrates discussing the art of sculpture with one Kleiton, a cypher for Polykleitos, the master of the Dorpyphoros (figure 12) the statue which perhaps best exemplifies the intersections between art and medical knowledge in this period. Sokrates explains the sculptor's success in producing real-looking statues in terms of his knowledge of, and ability to represent, exactly the same mechanical features of movement as described by the Hippocratic authors in their analyses of joints and fractures, 'both the pressing and the pulling movements (sympiezomena kai dielkomena) and the tensions and relaxations (enteinomena kai ta aniemena), ${ }^{\mathrm{xxxix}}$

The ideal man was both sinuous (neurodes) and well-tensed (eutonos); these features being taken in both the Hippocratic writers and the pseudo-Aristotelian Physiognomonica as indicators of courage and strength of character. ${ }^{\mathrm{xl}}$ The antitiype to this Hellenic ideal was embodied by Asiatics, in particular the Persians, who had soft and spongy bodies, like those of women, and were correspondingly lazy and cowardly. ${ }^{x l i}$ The artistic counterpart of this ideal body was developed in the early classical period, in the aftermath of the Persian wars, and was particularly associated with the heroes of the battle of Marathon. As such it represented a democratic ideal, as much as an ethnic one, and in part entailed distancing from the more luxurious and soft styles characteristic of the archaic aristocracies, in particular of Ionia, and their emulation of eastern art and culture. The evocation of medical semeia of health, including superficial veins and signs of breathing in sculpture at least, also had a political dimension: the hygies aner, the healthy man, was also the man who knew the nature of true justice, and could thus bring benefit to his city, onesipolis. xlii This normative body aesthetic was realised not only in statues and paintings but also through sets of bodily practices, the athletic exercises which trained the ephebes for warfare. Both the statue of the Tyrannicides (figure 13), and the Florence Painter's Lapith (figure 14), inflicting justice on a hubristic centaur, embody this aesthetic and political ideal. Plato's description of the postures performed in the Pyrhhic dance could almost describe these two images: 'It tries to represent the more aggressive postures adopted when shooting arrows and discharging javelins and delivering various kinds of blows. In these dances which portray fine physiques and noble characters, the correct posture is maintained if the body is kept erect (orthon) in a state of vigorous tension (eutonon), with the limbs extended nearly straight (euthupheres)' ${ }^{\text {xliii }}$

Mimesis is, of course, the idea which brings together both these new naturalistic depictive practices, and the cultural concepts - schemata, rhythmoi, ethos - which are 
associated with them. We are perhaps most familiar with the concept of mimesis from Plato's Republic Book 10, as copy or imitation of appearance, and thus, in terms of Plato's theory of Forms, the antithesis of truth. But the sense in which Aristotle uses it in the Poetics passage discussed above goes back to the fifth century, where it has a more active connotation, linked to dramatic performance and implying impersonation, or the use of gesture to communicate meaning. ${ }^{\text {xliv }}$ Plato also in some contexts uses the concept in this more traditional sense. In the Protagoras, for example, he describes how children may be exposed to models from the past 'so that the child may eagerly emulate them and desire to become like them - iv $\alpha$ o $\pi \alpha \tilde{i} \varsigma$

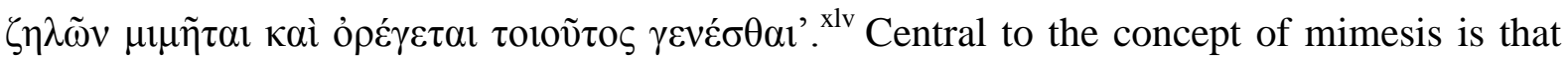
the forms, schemata, mediated through art, choric or pictorial, work their way into the psyche or the soul of the viewer; in particular that the viewer or performer will become assimilated to the tendencies or dispositions (tropoi) of character implicit in the exemplars of action which they imitate, emulate or take pleasure in. ${ }^{x l v i}$ Correspondingly, as Aristotle argued, there was nothing more important than becoming habituated (synethizai) 'to judge correctly and to delight in virtuous characters and noble actions', and equally to feel disgust and hatred at their opposites, whether we are looking at actions or representations of them, since, as he puts it, 'feeling pain and delight at representations of reality is close to feeling them at actual reality'. ${ }^{\text {lvii }}$

How were these very diverse components of Greek artistic, political and intellectual culture integrated in practice within a specific institutionalisation of art in classical Athens? We can conveniently address this question by focussing on two images. First, a depiction of the Centauromachy from the neck of a volute krater by the painter of the Woolly Satyrs (figure 15) which probably gives us our best impression of what the centauromachy in the Theseion may have looked like. ${ }^{\text {xlviii }}$ Second, the South Frieze of the Temple of Athena Nike on the Akropolis (figure 16), representing the Battle of Marathon, and perhaps quite closely dependent on the painting of the same battle in the Stoa Poikile. ${ }^{x l i x}$ At the center of the frieze of the volute-krater by the Painter of the Woolly Satyrs, a centaur and a human figure face each other. The former falls back, body and face alike contorted, cowering under the protection of a cushion, 'low and grovelling', the embodiment of what is 'worthless and hateful' as Socrates describes attitudes of the hybristes in his discussion with Parrhasios, in Xenophon's Memorabilia. ${ }^{1}$ The latter is an embodiment of the civic values described above: standing erect, with powerful physique, and well-tensed musculature, controlled and disciplined, this figure almost certainly represents Theseus, coming to the assistance of his 
friend Perithous, and represented with the posture of the Tyrannicide, Harmodios. Theseus and Harmodios were assimilated to each other as founding heroes of Athenian democracy: established, according to myth, by Theseus and restored by the Tyrannicides. A very similar figure recurs in the Nike Frieze: swinging his weapon above his head, courageously opening his body up to his opponent, and with his mantel falling about his legs, again closely related to Tyrannicide iconography. As Evelyn Harrison has argued, the iconographic assimilation of this figure to the Tyranncides recalls Herodotos' account of the speech made by the Athenian statesman and general Miltiades to Kallimachos, the polemarch, persuading him to take the initiative against the Persians before their army was fully disembarked on the plane of Marathon: 'Kallimachos, it is for you to decide whether you will enslave Athens or free her, and thereby leave such a memorial for posterity as was not left even by Harmodius and Aristogeiton'. 'i Both art and rhetoric function here according to a similar logic, formulating an analogical relationship between an historical or mythical exemplar and contemporary situation as a means of moral suasion, rather than appealing to the kind of abstract universal principles which inform later philosophical discourse. That is to say the rhetoric of classical Greek art operates according to the same cultural and cognitive logic as the correlative style of thought that is sometimes seen by sinologists as characteristically Chinese and nonwestern, an issue to which we will return later in this article. lii

We can well imagine how viewers might have responded to and evaluated these images, praising and taking pleasure in the actions of Theseus and Kallimachos, both fine and beautiful, while condemning and feeling disgust at the shameful and ugly centaur and Persian whose degraded nature is expressed in their contorted and cringing bodies. ${ }^{\text {liii }}$ But we should also be mindful of the specific character of the contexts in which these images were viewed, the kinds of activities which may have taken place at the same time as paintings were being viewed, and the entailments of these contexts of reception for the further discursive elaboration and mobilisation of the meanings encoded in their iconography. The Theseion, in addition to housing the bones of Theseus and being the focus of an annual festival in his honour, was also used from time to time as a meeting place for the boule, the governing council, as well as for some of the boards that administered the bureaucratic aspects of Athenian democracy; it was also a place of muster for troops gathering in preparation for military expeditions. ${ }^{\text {liv }}$ The Stoa Poikile, in addition to being one of the most prominent monuments of the core civic space of Athens, the agora, and thus a centre for political discourse and reflection, also served more specific functions of political administration, being 
used on occasion as a law court, for example. ${ }^{\mathrm{lv}}$ These contexts of reception not only framed the immediate viewing of such paintings, they also shaped the ways and purposes to which they were appropriated in broader arenas of civic discourse. The paintings of the Stoa Poikile, in particular the Battle of Marathon, are a recurrent focus of interest for the Attic orators, who use them to admonish their contemporaries to emulate both the courage and the moral standards of their forebears. ${ }^{\text {lvi }}$ In Aristophanes' comedy, the Lysistrata, we even find the iconography of narrative art from the agora being used as both a paradigm to interpret the situation and a model for action to rectify it. Lysistrata and her comrades have seized the Acropolis, and are seeking to conclude a peace with the women of Sparta. The chorus of knights interpret their actions as the thin end of a wedge which could lead even to the supplanting of the knights, the defenders of proper patriarchal democracy, and they invoke Mikon's Amazonomachy paintings as a terrible warning of what happens if women get out of place: 'Well a woman sticks on horseback: look around you see behold/Where on Mikon's living frescoes fight the Amazons of old!'. Elsewhere in the play, the female threat to democracy is answered with an invocation of the Tyrannicides, as the leader of the chorus draws himself up alongside the statues, assuming their posture, and striking one of the upstart women with a Tyranncidal blow of the kind familiar from the statues themselves and from the narrative paintings which echoed their iconography. ${ }^{\text {lii }}$

What then do the depictive practices we subsume under the concept of naturalism accomplish in the context of this institutionalisation of art, and how should we explain them? As I have suggested, naturalism appropriated the natural affordances of the body as a core component in the construction of classical style and iconography. As such, it provided the means to articulate or suture into a unified representational system a wide range of social practices and cultural discourses - from ritual dance and athletic exercise to medical theory and moral discourse. These diverse semiotic practices were integrated into a language of visual representation which, by virtue of its bodily bases, had a quite compelling power in shaping the identities of its viewers to fit the moral order that underwrote the increasingly elaborate, and institutionally differentiated, Athenian state which was constructed during the first half of the fifth century BC. Naturalism offered both a bodily anchor for such cultural discourses, and a medium for their practical incorporation as core components of citizens' sense of self, all as part and parcel of the remaking of civic identities which the new structures of the Athenian state entailed. ${ }^{\text {lviii }}$ 


\section{CHINESE NARRATIVES}

So far as we can judge from the textual evidence, mainly dynastic histories, the primary contexts for the development of narrative art in the Han were the imperial palaces, and educational institutions like the Confucian academies where aspirant officials received their education. ${ }^{\text {lix }}$ The textual evidence points to quite elaborate programmes of narrative art in the imperial palaces as early as the Former or Western Han, including screen paintings, wall-paintings and scrolls. This interest continued into the Eastern Han, perhaps on an intensified level. ${ }^{\text {lx }}$ None of these paintings survive. Instead, our material evidence for Han narrative art consists almost exclusively of tomb paintings and engravings, some from as early as the Late Western Han, the second half of the first century BC, the majority from the latter half of the Eastern Han, first two centuries AD. We find pretty much the same range of themes in the funerary contexts as are mentioned for the narrative paintings in imperial palaces. ${ }^{1 x i}$ Furthermore, parallelisms between inscriptions on some of the tombs, and contemporary descriptions and responses to palace paintings, suggest that they had a broadly similar moralising function. ${ }^{\text {lxii }}$ Consequently, it seems reasonable to suppose that the later funerary repertoire is developed out of, and in certain respects emulates, earlier Han imperial painting, and as Martin Powers has suggested may at least in part have been intended as a tacit criticism of what were perceived as moral shortcomings of the late Han court. ${ }^{\text {xiii }}$

Han narrative art introduces a number of innovations on late Warring States figurative art which bear comparison with their early fifth century Greek counterparts, in particular a wide range of expressive gestures, and the interrelating of groups into more cohesive units, through the use of three quarter compositions, contrapposto and mutual gaze, all suggesting a certain psychological rapport between the figures, heightened by an increasingly rich and subtle repertoire of facial expression. ${ }^{\text {lxiv }}$ A quick look at a few examples gives a sense of the general pattern, and some of them we will pick up in more detail as we progress. A tomb relief from Sichuan shows the story of Qiu Hu's wife from the Han Lie nu zhuan (Biographies of Outstanding Women) (figure 17a-b): returning after five years absence from home Qiu Hu stops to make a pass at a beauty picking mulberry's beside the road. The beauty is in fact his wife, but they do not recognise each other until he arrives home, when she upbraids him for his immoral behaviour and, overcome by shame, throws herself into the river. The relief depicts the encounter on the road, with Qiu Hu importuning the alluring female, contrapposto and mutual gaze evoking the psychological interaction, and the wife's adhesion to the mulberry tree suggesting her chaste rejection of the stranger's advances. ${ }^{1 \mathrm{xv}} \mathrm{A}$ 
similar sense of psychological interaction is captured between two figures on a set of painted tiles from Luoyang, now in the Boston Museum of Fine Arts, possibly depicting the encounter between Confucius and Laozi; we also get here a sense of something of the subtlety of Han facial depiction not so easily captured in stone-engravings (figure 2). ${ }^{\text {xvi }}$ A very different quality of interaction, and a different character in the protagonists' relationship, is evoked in a tomb-engraving from Yinan. The self-possessed Zhang Liang looks on placidly as the snarling Fan Zeng smashes the a white-jade dipper he had been presented by Zhang Liang, after the latter had foiled Fan Zeng's plot against his master, Liu Bang the founder of the Han dynasty, at the famous Hong Meng banquet (figure 18).

Whilst we do not have such elaborate descriptions of Han paintings as those of Pausanias describing the paintings of Polygnotos, we do have some very suggestive analyses of paintings from the Wei and Jin dynasties, the immediate successors of the Han, in the fourth century painter Gu Kaizhi's Lunhua, Discourse on Painting. Many of the paintings he evaluates are of the same themes as evidenced for the Han, and Gu Kaizhi's focus in responding to them is very much on expressive gesture and facial expression and their role in visual narrative. ${ }^{\text {xvii }}$ Describing a scroll of paintings based on narratives from the Biographies of Outstanding Women - the source for the Qiu Hu story already mentioned - he comments, 'The faces in it look resentful, and the attitudes are as though carved and chiselled, but he has not go to the depths of the vitality (of the subjects), 不盡生氣'. He describes a painting of the story of Sun $\mathrm{Wu}$, who had demonstrated his prowess as a trainer of soldiers on the king's harem, starting by executing the two female captains when the concubines under their command simply laughed at the sound of the drum, signalling a command. 'The two beauties', Gu writes, 'afford an example of startling drama by their pitifully lovely bodies' (二婕以憐美之㡟有驚劇之則). ${ }^{\text {lxviii }}$ A scroll depicting 'Brave Warriors', showed them in 'running and leaping postures (or 'shi'有奔騰大勢)', but failed 'successfully to render the attitude (tai) of valour' (不盡激揚之態). ${ }^{\text {1xix }}$ Similarly, in a painting depicting scenes of Virtuous Women, probably by Wei Xie a late third century painter, he talks of the figures as being ‘dignified' and having ‘expressive gestures’ (or 'disposition’) (情勢). ${ }^{\text {1xx }}$

The term used to describe the gestures or postures of the figures in the latter two cases is shi, 勢。It is generally assumed that the concept shi came into Gu Kaizhi's text via calligraphy theory, in which it acquired a considerable importance from the late second century $\mathrm{AD}$, as a way of conceptualising the configurative force or energy of brush work. But 
the notion of shi as 'dynamic configuration', ${ }^{\text {lxi }}$ or propensity, and in particular its association with $q i$ - vital breath, long predates the development of calligraphy, and was in fact significant in a number of domains of thought and practice in the late Warring States and early imperial period. The term refers to a kind of internal or potential energy given by position in a configuration: the potential energy of a mass of water, penned up behind a dam, for example; or a cross-bow stretched to its maximum. ${ }^{\text {1xxii }}$ It is used as early as Guanzi in the third century $\mathrm{BC}$ to describe the configuration of terrain, in particular the lifelines along which $q i$-vital cosmic breath - flowed, concentrating at their ends. ${ }^{\text {lxiii }}$ The term is also used in early Han medical texts, describing positions and postures in various exercises in body cultivation, which aimed to preserve the health and promote the vitality of their practitioners. ${ }^{\text {lxxiv }}$ The 'Shi shi' (十勢 ten postures), describes a range of sexual positions thought to be particularly conducive to maintaining one's health, all named on the basis of analogies with patterns of animal movement, such as Roaming Tiger, or the Gibbon Squat. ${ }^{\text {lxxv }}$ More important to our immediate purposes is the rather fragmentary Daoyin Tu (導引圖), or Guiding and Pulling Chart, an illustrated manual of exercises involving gentle stretching movements and controlled breathing, designed to reduce tensions within the body, and regulate the flow of $q i$, vital energy. Here too we find shi named by analogy with a pattern of animal movement: The Dragon Ascending, the Bear Rambling, the Monkey Bawling to Pull Internal Hotness, for example (figure 19). ${ }^{\text {lxxvi }}$ In each case the shi implies a whole sequence of movements, and with it the enhancement and regulation of corporeal energy flows which the exercise entails. ${ }^{\text {lxxvii }}$ If the Greek rhythmos is the stop which encapsulates a movement, shi is the potential movement or dynamic energy implied in a posture or position, the force that runs through a figure and animates it. ${ }^{\text {lxviii }}$

We can explore how these ideas might be relevant to the body and gestural language of visual art by looking at some paintings from another Western or Former Han tomb painting from Luoyang, telling the story from Yanzi's Spring and Autumn Annals, 'Two Peaches Kill Three Warriors' (figure 20a-b). ${ }^{\text {lxix }}$ The story tells how Yan Ying, as Primeminister of the State of Qi, tricked three warriors of the court who had failed to respect his authority and thus threatened the balance of power within the state. Rather than confronting them directly, he had the Duke of Qi send two peaches to the warriors, to be divided amongst them according to their personal merits. The first two, Gongsun Jie and Tian Kaijiang boast of their military exploits, and each takes a peach, exclaiming confidently that their feats could not be surpassed. The third, Gu Yezi, trumps their exploits with a story of how he had slain a 
giant river tortoise, and been acknowledged by the local population as Lord of the River; he demands that his comrades hand over the peach that is his due. Acknowledging Gu Yezi's superior achievement, the former two heroes return their peaches; humiliated, and wishing to vindicate their reputations for courage, they kill themselves with their own swords. Gu Yezi, mortified that he had caused his own friends death through a lack of Confucian benevolence and propriety (ren and yi), also kills himself. Two figures on the left attend the Duke of Qi; the half turning figure is probably Yan Ying, said to be very small, and a third attendant surveys the table with its peaches. To the right are the three warriors: the moment depicted seems to be $\mathrm{Gu}$ Yezi claiming his peaches, and his comrades about to slay themselves. The strength of their emotions is captured in their dynamic postures and exaggerated facial expressions, with glaring eyes and flying hair and whiskers. It is underlined by the billowing drapery, which seems to take on a life of its own, its dynamism reinforced by the rhythm of the lines, thickening and thinning as they burst out from the center of each figure. ${ }^{1 \mathrm{xx}}$ They stand in strong contrast to the self-possessed, largely motionless figures of Yan Ying, the Duke and his officials. $1 \times x \times i$

On one level this imagery is relatively transparent: wide-open bulging or glaring eyes are an index of anger in many mammals, not just human beings; and Gestalt psychologists have described the mechanisms by means of which we are naturally predisposed to see long wavy lines as indicators of movement. ${ }^{\text {lxxii }}$ As in the Greek case, however, these transparent signifiers are overwritten in cultural terms peculiar to a specifically Han Chinese politics of the body. In a late Warring States medical text, the Huang di nei Jing or Yellow Emperor's Classic of Medicine, the brave man is described as follows: 'The brave man's eyes are deepest and fixed. The hairs of his long eyebrows rise up. His Triple Burner (san jiao, 三焦) is ordered and horizontal. His liver is big and sturdy. His gall bladder is full to overflowing. When angry his qi energies overflow and his chest swells. His liver rises and his gall-bladder moves horizontally. His eyes bulge from his their sockets, his hair rises up and his face flushes. This is the manner of the brave man'. The specific features characteristic of the iconography of the Three Warriors thus embody this ideal of the brave man, manifesting his qualities in the context of action motivated by righteous anger, his superabundant qi energy, animating his limbs, streaming out through his skin and hair, and even his drapery, overflowing into the world beyond. ${ }^{\text {lxxiii }}$ 
This set of features, described in physiognomical texts in terms of the 'air of valour, qi jie, ${ }^{\text {lxxxiv }}$ is not uncommon in early imperial Chinese art. A Han mirror (figure 21) depicts the story of $\mathrm{Wu} \mathrm{Zixu,} \mathrm{a} \mathrm{minister} \mathrm{of} \mathrm{the} \mathrm{King} \mathrm{of} \mathrm{Wu}$. The latter was offered two beautiful concubines by the King of Yue. Wu Zixu, aware of his own king's lack of continence, recognised Yue's underhand plot, and advised against accepting the gift. But a scheming prime-minister spoke against his advice, and the king took $\mathrm{Wu}$ Zixu's admonition as an expression of disloyalty. Depending on what version one follows, Wu Zixu either drew his sword in the court, - and was subsequently disarmed and killed - or was sent a sword as a gift by the king a few days later, and used it to take his own life. The mirror shows the King of Yue and his prime-minister plotting at the top, the two beauties on the left, the King of Wu seated before a screen on the right, and the suicide of Wu Zixu at the bottom. An almost identical figure is found in an unidentified encounter amongst a set of narrative scenes from a late Han tomb at Yinan (figure 22), and the glaring eyes and flying hair and whiskers are characteristic also of Jing Ke, the would be assassin of the King of Qin, later First Emperor, from the same tomb, though since he is naked to the waist animated drapery does not play an equivalent role. ${ }^{\operatorname{lxxv}}$ As Eugene Wang has argued, the air of valour was specifically associated with a new category of 'singular deeds', $d u$ xing, recorded in the histories of the later Han. ${ }^{\text {lxxxi }}$ They seem to have been particularly linked with loyalty towards the ruling dynasty, manifested to the extreme of death: one Wang Jia, for example, on receiving a messenger sent by the usurper Wang Mang, summoning him to service, simply slew himself with his own sword on the spot, in front of the messenger. Another, Li Ye, took poison rather than be constrained to fight on behalf of a rebellious general, for which he was honoured with a painted portrait by the emperor Guangwu. Not all such acts of singular bravery resulted in death of course, and renown for having performed such an act would enhance an individual's eligibility for promotion within the official career ladder of the later Han bureaucracy. ${ }^{\text {lxxxvii }}$

As we have already seen, the category of $q i$ was relevant to other modes of comportment and types of excellence, and the manifestation of appropriate regulation of $q i$

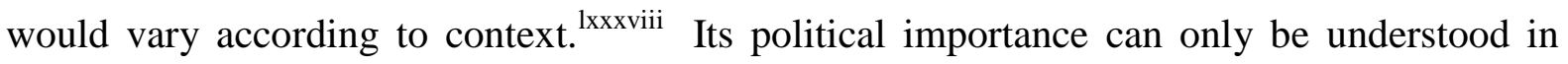
terms of the larger context of Han cosmology according to which qi, in varying degrees of refinement, mediated the relations between Heaven, Man and Earth, ensuring both their mutual harmony, and the orderliness of terrestrial and heavenly events. $Q i$ could be watched for in varying manifestations and with varying levels of expertise. There were specialists who could observe and evaluate the $q i$-energy of opposing armies, on behalf of their generals; 
others who looked to cosmic qi, to detect propitious shifts in the balance between yin and yang, or more prosaically to predict the weather. ${ }^{\text {lxxix }}$ But all of these practices are logically, and in terms of Han cosmology, substantively correlated with the physiognomic reading of $q i$, above all in the persons of the emperor and his officials, since it was their self-regulation of their $q i$ which legitimated their political and social status. Their capacity to control the accumulation, regulation and consumption of qi-energy placed them in a position to harmonize, sometimes forcefully, relations between men, and at the same time to rectify or harmonize the relationship between the world of men, the earth and the heavens that guaranteed the imperial order of the Han, whether through acts of singular valour, like Jing $\mathrm{Ke}$, seeking to overthrow the illegitimate tyrant Qin, or through the more everyday practices of self-harmonization and moral rectification effected by sage-ministers and educated officials. $^{\text {xc }}$

Like their Greek counterparts, these early imperial Chinese visual narratives lent themselves to a response in which the moralising and the expressive-aesthetic were fused. Cao Zhi, writing in the twilight of the Han, comments: 'Of those who look at pictures, there is not one who, beholding the Three Majesties and the Five Emperors - [all legendary culture heroes of the bronze age] - would not look up in reverence (莫不仰戴), nor any that before a painting of the degenerate rulers of the Three Decadences would not be moved to sadness. There is no one who seeing a picture of usurping ministers stealing a throne would not grind his teeth... At the sight of loyal servants dying for their principles who would not harden his own resolve (莫不抗節); and who would not sigh (莫不歎息) at beholding banished ministers and persecuted sons. Who would not avert his eyes (莫不側目) from the spectacle of a licentious husband or a jealous wife, and there is no one who, seeing a virtuous consort or an obedient queen would not praise and value them (莫不嘉貴)', a vocabulary equally applicable to the painting and the actions they depicted. ${ }^{\mathrm{xci}}$

Cao Zhi's words recall the pictorial narratives which we have already come across in paintings and engravings from tombs: loyal ministers like Wu Zixu, dying for his principles, or licentious husbands like Qiu Hu making a pass at the alluring stranger who turns out to be his wife. But what were the primary contexts and occasions of these moralising viewings which Cao Zhi describes? As in Greece, though with differences corresponding to the different political structure, contexts for the display and reception of paintings shaped the 
ways and purposes according to which they were appropriated into broader arenas of discourse.

As I have already mentioned, the primary context in which we are informed of the development of sets of narrative paintings are imperial: the creation of sets of wall-paintings in the palaces, or screen paintings which might frame the emperor's presentation in the contexts of receptions or rituals of dining; sometimes also scroll paintings for more personal perusal, on the part of the emperor and his courtiers, particularly wives and concubines. ${ }^{\text {xii }}$ It is particularly telling that the $f u$ prose poems, commissioned by both emperors and the regional kings of the Han and the immediate successor dynasties to describe and celebrate the architecture and lavish decoration of their palaces, might include descriptions of paintings with exactly these moralising themes. ${ }^{\text {xiii }}$ Appropriate sets of paintings, demonstrating that one revered the virtues of the former kings, and inculcated appropriate principles of modesty and self-abnegation into one's wives and consorts, was an essential component of the selfpresentation of men of authority and power. The paintings are described precisely as exemplars and models, to be perused day and night, and emulated, or avoided as appropriate, if the primary viewer - the emperor himself - is to establish a harmonious order. ${ }^{\text {xciv }}$

Correspondingly, invocation of such narrative paintings forms a topos in the Han histories, in accounts of the admonition of emperors by ministers and courtiers, of emperors' efforts to shape the character and actions of their courtiers and officials, and equally, further down the social hierarchy, of officials to rectify the conduct of persons in communities over which they had authority. Perhaps the most famous example is the story of Lady Ban who, invited by the Emperor Cheng to ride with him in his carriage declined, commenting: 'In the paintings of ancient times one always sees the sage rulers with eminent ministers by their side; only the last rulers of the Three Dynasties [the Xia, the Shang and the Zhou], the men who brought destruction to their lines, have their women favourites beside them. Now, if you invite me to share your carriage, will you not appear to resemble the latter? ${ }^{\text {, }}{ }^{\text {cv }}$ This particular story became a moral exemplar in itself, and is found illustrated in scrolls and screens of the Six Dynasties period. ${ }^{\text {xcvi }}$ Perhaps because they make for better stories, it is the use of the negative exemplars that are most often mentioned in the Dynastic Histories. As Grand Master for Splendid Happiness (Guanglu Daifu), the minister Ban Bo's responsibilities included moral admonition of the emperor. One day the emperor was seated in front of a screen on which Zhou, the last Shang emperor, was painted at the end of a night of drunkenness and 
debauchery, propped up on the shoulder of his evil consort Da Ji. 'Was Zhou really immoral to this extent?' the emperor asks Ban Bo. Ban Bo's answers to the emperor are quite oblique, alluding to the Book of Documents criticism that Zhou had unwisely relied on the advice of women, he comments that 'All filth flows downstream', and that therefore the Zhou could not be said to be wholly wicked. The emperor demands further clarification: 'If this is not the case, then what is this painting admonishing me about?' Ban Bo then replies that it was Zhou's drunkenness that stirred the criticism of his minster Weizi, to the extent of his resignation, and then runs through a series of quotations of Classic texts concerning the alcoholic roots of immorality and disorder.

Remonstrating with the emperor may have required more tact and subtlety than was necessary for the Attic orators, in their speeches to the demos. Ban Bo, in the example mentioned above, pointedly did not explicitly comment on the corrupting influence of the Shang Emperor's consort Da Ji, wary of the power of Emperor Cheng's consort and prospective empress Zhao Feiyan. ${ }^{\text {xcvii }}$ Within the intensely political environment of the court, any kind of a comment on a painting could be taken as political comment, whether intended or not, with extreme consequences. One palace-official, Yang Yun, Chamberlain of the Attendants, looking at the paintings displayed in the Western Pavilion of the palace the Western Han Emperor Xuan, commented to his companion that when the emperor had come to the pavilion to look at the paintings of good and bad rulers, he had shown special interest in the paintings of the wicked rulers Jie and Zhou, the last kings of the Xia and Shang dynasties. Indeed, according to Yang Yun, the emperor 'asked to hear about their sins in great detail so that he could learn to emulate them'. Within a short time, word of Yang Yun's comments spread. He was dismissed from his position, stripped of his rank and ultimately tried and executed on a charge of gross immoral conduct, dani budao, a generic charge for anyone who directly criticised the emperor. ${ }^{\text {xcviii }}$

The cultural logic that informs the remonstrative use of narratives in paintings parallels that which we have already seen in the Greek case, in particular in relation to the imagery of the Tyrannicides. A story in the Han History tells how, when the emperor $\mathrm{Wu}$, bereft of adult heirs, plans to designate one of his younger sons as heir, he realised that the child would need the assistance of a trusted minister to govern as regent. Correspondingly, he presented his chief minister He Guang with a painting of the 'the Duke of Zhou bearing on his back the infant king Zheng and receiving the feudal lords in audience' ${ }^{\text {xcix }}$ The implication, 
spelled out later in the text, was that He Guang was to play the role of the Duke of Zhou in relation to the emperor Wu's successor: the Duke had similarly acted as regent on behalf of the successor of the founder of the Zhou dynasty, resigning as soon as the latter reached the age of majority, rather than usurping the position of emperor, as was so often the case.

The remonstrative use of visual narratives extended beyond the context of relationships between emperors and officials, into broader social and political worlds. The $\mathrm{Wu}$ Liang shrine is a good example of this, since its pictures seem to have been intended to have a moralising effect on both $\mathrm{Wu}$ Liang's descendants, and the larger community of which they were members. ${ }^{c}$ One of the stories on the $\mathrm{Wu}$ Liang shrine is that of the filial Boyu (figure 23). Beaten by his mother one day, he bursts into tears. The mother comments: 'I did not see you weep when I punished you before. Why do you cry today?' Boyu replies: 'Before when I offended you and you beat me with the stick, I often felt pain. But today your strength could not make me feel pain. That is why I am weeping'. The pictures from the shrine show Boyu with arms raised to his face, to wipe away his tears. The morally transformative power of such visual narratives is nicely encapsulated in a story from the later Sui dynastic history, which tells how a man charged with unfilial conduct was brought before the district administrator. Rather than punishing him directly, the administrator seeks to rectify the unfilial man's conduct. He sends him to look at a painting of the story of Boyu in the local Confucian College. Moved by the painting, the unfilial man was transformed to a model of moral rectitude. ${ }^{\text {ci }}$

\section{UNDERSTANDING AND EXPLAINING NATURALISM: THE COMPARATIVE ADVANTAGES OF COMPARISON}

So how does comparison with the Chinese case illuminate our understanding of the classical Greek material, and vice versa? First, a comparative approach sharpens our understanding of 'naturalism' both as a general artistic phenomenon, and in its specific cultural manifestations in classical Greece and early imperial China. I have suggested that the narrative art of both classical Greece and early Imperial China drew upon a similar set of natural affordances of the body and of visual perception in formulating artistic styles and iconographies which permitted a much richer articulation of the relationship between persons represented interacting in such narratives, and a much deeper and more elaborately culturally 
articulated psychological engagement with those narratives on the part of their viewers than had been characteristic of the two traditions in earlier periods.

This is not to deny that there are important cultural differences, but those differences are not such as to constitute incommensurable traditions which can only be understood as expressions of radically discrepant cultural mentalities. On the contrary, the specific character of the two traditions is created by placing distinctive cultural constructions on, and differentially elaborating, bodily and perceptual affordances, and depictive strategies, which were at least on some level shared by both traditions. Some of the strategies are too all intents and purposes identical: the development of three quarter representations to suggest dialogical relationships; an interest in expressive gesture; the use of the gaze as a means of articulating relationships within groups; the focus on bodily posture and facial expression as manifestations of character. The culturally specific terms within which posture and gesture are conceptualised and interpreted are, of course, indicators of cultural difference: schemata, rhythmos and eutonia on the Greek side; shi, propensity, and qi, vital energy, being the key concepts on the Chinese side. But the visual forms used to represent these concepts are ones which were shared by artists of both traditions in the context of the development of depictive strategies to animate the body. Chinese artists were quite capable of representing welldeveloped muscles as indicators of a powerful body, as manifested in a late Warring States funerary figurine depicting a warrior with powerful looking calf-muscles (figure 24) and in a strongman or acrobat from the tomb of the First Emperor. ${ }^{\text {cii }}$ But the particular cultural conceptualisation and politics of the body characteristic of the Han meant that the possibilities of this particular motif were little developed. Indeed, in the rare occasions where we do find an emphasis on the muscled character of a figure, in depictions of tomb-guardians and warriors like those from tomb M1 at Houtun, the bulging calf-muscles are transformed into linear motifs, in the form of a calligraphic flourish (figure 25). ${ }^{\text {cii }}$ Similarly, Greek artists could represent flying drapery, as a means to animate the body. Indeed such flying drapery is held to be one of the signal characteristics of late fifth century art, and is even described as being 'calligraphic, in its character (figure 26). ${ }^{\text {civ }}$ But the fluid line of such drapery never seems to have taken on the deeper cosmological resonances characteristic of its Chinese counterpart, nor to have been extended to the hair, beards and whiskers of Greek warriors as it was in China, in the context of the concept of $q i$ as vital energy mediating the relationship between the individual and his or her larger social, political and cosmic contexts. 
Second, a comparative approach has served to illuminate the social and political circumstances under which narrative and naturalism became a central preoccupation of both artistic traditions, and as such to offer a compelling alternative to the more provincial explanations of the development of naturalism developed on the basis of isolated studies of the two cases - whether the special character of Homeric poetry and the open society in the Greek case, or a 'natural' evolution, perhaps stimulated by Western influences in the Chinese case. ${ }^{\text {cv }}$ Instead, comparative analysis seems to suggest that in both cases the development of narrative art and naturalistic representation was linked to the development of broadly homologous institutions of art which served to inculcate in viewers an attachment to new moral codes which were the basis of the integration of new more differentiated state institutions characteristic of classical Athens, the primary source of the new developments in the Greek world, and early imperial China. The new art was intimately linked with new styles of behaviour which served to define the political elites of the two state systems in question, and indeed their citizens and subjects. The heightened interest in the body and interaction in classical Greek and early imperial Chinese art is linked to the changing character of social relations in societies with a political realm now differentiated from the contexts of kinship and religion, and at least partly secularised. The development of this realm entailed changing patterns of social solidarity to permit the collaboration, often competitive but also rule bound, which underlay the ongoing construction and reproduction of this new social order. New forms of solidarity, and new forms of interaction, placed a premium on the elaboration of increasingly demanding and universalistic codes of moral values. Narrative art, with a broadly naturalistic character, offered a means for the exploration these moral codes and for the inculcation of the substantive values which informed them, distinct in their specific contents in Greece and China, but pitched at a broadly equivalent level of cultural abstraction which explains the broadly parallel developments in artistic style. The new codes of behaviour focussed an interest on the body and interaction, as the means through which these new moral codes were manifested and inculcated. On a conceptual level this is manifested on the parallel development of body-state analogies in classical Greek and early imperial Chinese thought. ${ }^{\text {cvi }}$ The development of artistic institutions which placed an emphasis on narrative art, and naturalistic styles of representation, made real the conceptual metaphors which informed body-state analogies, quite literally bodying them forth as sensuously engaging models for the embodiment of forms of ethical and political personhood which were at once grounded in the affordances of the living human body, and shaped by the distinctive moral codes of the early imperial Chinese bureaucratic state, and the egalitarian 
and participatory Greek citizen-state, manifested in particularly strong variant by democratic Athens.

\section{ACKNOWLEDGEMENTS:}

Early versions of this paper benefitted from the questions and comments of audiences in Cambridge and Oxford. Jas Elsner, Robert Harrist, Geoffrey Lloyd, Michael Nylan, Jessica Rawson, Michael Squire and Roel Sterckx all commented on revised versions. I am grateful to them all for their assistance which has materially improved the final version; shortcomings are of course my own. 
${ }^{\mathrm{i}} \operatorname{Lim}$ (1990) quotations 83-4, 94. The parallel between Greek geometric art and the style of early Chinese pictorial vessels is also remarked by Jabobson (1984).

ii The model goes back, of course, to Winckelmann. Classic recapitulations of the argument include Loewe (1907) and Gombrich (1960), chapter 4 'Reflections on the Greek Revolution'; for a standard account of the development of naturalism in Greek art, couched in similar terms to Liu: Robertson (1975) A History of Greek Art, chapter 4 'The great change'.

iii Fong $(2008$, 9), although Fong seems to emphasize a later starting point then Lim, emphasising the Eastern Han as the moment of breakthrough, rather than the Western Han.

iv And, indeed, that starting from the Greek world irredeemably vitiates the comparative enterprise from the start, since it sets up the comparison in terms which cannot be neutral between the two traditions. There is, of course, some truth in such criticisms, but they are predicated on the assumption that one could start from some kind of degree zero comparison, which is simply not realistic. Different starting points for a comparison will bring out different similarities and differences, and make different contributions to enhancing our understanding of the materials at hand. That said, a strong case can be made for classical Greece as a fruitful point of comparison with China. Histories of Western art, ultimately derived from Hellenistic histories of Greek art, via Pliny and Vasari, have been a key point of reference for Chinese art history writing since its institutionalisation as an academic discipline in the twentieth century in both the West and China (Wang 2011; Elkins 2010). Even contemporary Chinese art history writing is almost unavoidably tacitly comparative. Quite apart from more explicit allusions, like Wen Fong's 'Han-Tang Revolution' it is worth pointing out that recent work on narrative in Chinese art is based on categories originally developed by Kurt Weitzmann (Chen 1995; Murray 2007) for the analysis of narrative art in classical antiquity. That is to say, classical art is part of an unavoidable hermeneutic context for Chinese art history. The issue is not whether we compare or not, but how explicit that comparison should be, and what criteria one should use in formulating and evaluating comparisons, in terms of their fruitfulness and their well-groundedness. Certain aspects of Han art and society have, for example, been usefully compared with the art of eighteenth century France by Martin Powers (1991). One difficulty with Powers comparison, however, is that whilst it works quite well in suggesting parallelisms between Han China and eighteenth century France in terms of the sociological contexts and entailments of art 
production and consumption - for example the role of the aristocracy as a definer or taste, and the development of an increasingly open society in which a more broadly based public opinion might be mobilised against aristocratic conspicuous consumption - there are rather few helpful points of comparison between the specifics of artistic styles in the two periods; consequently in formulating his own account of archaism in Han Art, Powers draws on Meyer Schapiro's formal description of Romanesque style (Powers 1991, 115-121; 1981) which is of course radically discrepant in its articulation with a broader social context from the art of either the Han or eighteenth century France. In comparing classical Greece and early imperial China, as we shall see, one is at least able to maintain consistency across the social and the artistic levels of analysis, which makes for a sharper and more (or at the very least differently) illuminating comparison, exploring the two cases as 'variations on common possibilities' (cf. Summers 2003, 17).

${ }^{\mathrm{v}}$ There is a tradition of thought, dating back to Franz Wickhoff (1988, o.v. 1900), which argues that the development of Chinese, and East Asian art more generally, can largely be explained as the distant result of western, ultimately Greek influences. In Wickhoff's case, the underlying ideological agenda was to explain how Japanese art in the nineteenth century could influence the art of the more advanced West; of course, if Japanese art was ultimately indebted to ancient Greek stimuli, this could be reframed as Western art returning to itself. As it turned out Chinese bronzes in which Wickhoff detected the influence of Attic black-figure eye cups are much earlier than their supposed source, so Wickhoff's article is now just something of a historiographic curiosity. Nevertheless, recent research has demonstrated that there was a continuous flow of culture from the 'West' (Central Asia, Persia, the Steppes) from the late bronze age onwards, varying in intensity and impact (Rawson 1999). Disregarding for the moment, the intrinsic weakness of arguments formulated in terms of influences (cf. Baxandall's 'Excursus against influence' 1995, 58-62; and Powers 1991, 20-3 on the 'viral model'), there are two possible sources of 'influence' which could complicate the argument I make here which sees the development of narrative and naturalism in Greece and China as largely independent phenomena. First, it has recently (Barnhart 2006; Nickel 2013) been suggested that the Terracotta Army of Qin Shihuangdi (r. 221-207 BC) was influenced by the sculpture of the Greek cities of Hellenistic Central Asia - largely on the basis of the, arguably, otherwise unprecedented monumentality and interest in the representation of musculature in some of the figures. As Nickel points out $(2013,414,427)$, even if we accept this influence, it seems to have been extremely brief, and to have had little 
impact on the subsequent Chinese artistic tradition, since later funerary figures eschew the monumental scale and the interest in musculature, and revert to earlier means - moveable limbs and real clothing - to blur the boundary between image and the prototype it stood in for in the context of the tomb. The more credence one gives to Barnhart and Nickel's arguments the more striking the differences between the specific cultural inflections of naturalism in the Greek and Chinese cases, as analysed below, becomes, since musculature, central to the Greek enlivenment of the body, plays no significant role in the Chinese narrative paintings. The same applies to earlier versions of the same argument, like that of Rostovzeff, tracing Han naturalism to the influence of the Greek world, via the art of the Steppe nomads (Rostovzeff 1929, 79-106), criticised Powers (1991, 20-3); tellingly, the influence of the art of the Steppe nomads is also used to explain the earlier development of the non-naturalistic figure scenes of Warring States pictorial vessels (Jacobson 1984; Weber 1968, 223-37). Secondly, Chinese narrative art is demonstrably affected by the influence of Indian Buddhist art, but this appears only after the Han. Although there is evidence of 'Buddhist' iconography in Han China, it takes the form of single self-contained motifs, for example an image of the Buddha meditating, integrated into sets of images structured in Chinese terms, for example as xiangrui, images of good omen, rather than elaborate narratives (Wu Hung 1986). The consensus position is that Han secular narrative painting was not significantly influenced by Buddhist traditions, which become much more important as a factor in the period of the Six Dynasties (Chen 1995; Murray 2007).

${ }^{v i}$ Gombrich (1960) 99-125; quotation Gombrich (1982a) 20.

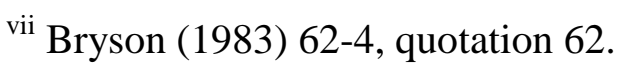

viii Bryson (1983), 13-15.

${ }^{\text {ix }}$ Soper (1948), 'Life, motion and sense of space in early Chinese representational art', 167; Rowley (1959), 24-6, on progressive character of Chinese art, with a development paralleling the stages of archaic, classical and Hellenistic, the art of the Wu Liang Shrine corresponding to the archaic phase - with discussion of Wu Hung (1989) 52-4.

${ }^{x}$ Pope (1947), Silberberg (1987), Wu Hung (1989) 50-56.

${ }^{x i}$ For example: Su Shih 1037-1101 'anyone who judges painting by form-likeness has the insight of a child' as quoted Wen Fong (2008) 19. It is worth noting that one can find similar statements in ancient Greek texts, even if they do not become a dominant trend in the critical tradition in the same way as in China: note, for example, Philostratos Imagines 1.9.5: someone who praises the realism of hair of the goats, or the puckered lips of the pipe-playing 
goatherds in a painting, would be praising only 'an insignificant (smikron) feature of the painting, and one which has solely to do with imitation (mimesis); but we would not be praising its cleverness (sophian) or the sense of fitness it shows (kairon), though these are, I believe, the most important elements of art (techne)'.

${ }^{x i i}$ Powers (1984); Powers (1991) 352-4, fig. 148 for perspective in Zhu Wei shrine.

xiii Wu Hung (1989).

${ }^{\text {xiv }}$ Powers (1991).

${ }^{x v}$ Bush (1971) 21-82 'The views of the Northern Sung Literati'.

${ }^{x v i}$ Acker II.18-19.

xvii Wu Hung (1989) 53, fig. 28 - discussing Soper's characterisation of the shrine's supposedly 'provincial' character whilst still retaining traces (aggressively three dimensional unit) of characteristics of art of the 'center' - i.e. the capital - missing the point as Wu Hung remarks.

${ }^{x v i i i}$ Fong (2008) 5-14.

${ }^{x i x}$ Although different styles of brush-writing were classified in the early Han, and varying levels of competence recognised, it is only in the second half of the second century AD that calligraphy emerges as self-conscious art form, as marked by treatises like Zhao Yi's Fei Caoshu (Against Cursive Script); see Escande (2003) 47-8, 74-84.

${ }^{x x}$ Summers (2006) 217. Cf. also his monumental Real Spaces (2003).

xxi Johnson (2007).

xxii Witkin (1995), Witkin (2005).

xxiii Boardman (2005).

${ }^{\text {xxiv } H a n f m a n n ~(1957) ~} 77$.

${ }^{x x v}$ Hanfmann (1957) 74.

${ }^{x x v i}$ Argyle and Cook (1976) 1-4, 27-30; quotation p. 3. The ethological findings are now underpinned by neuropsychology, and in particular investigations of mirror neurons, which have been able to localise, and in some degree characterise, activities in the brain demonstrating the character of these responses: Johnson (2007) 38-40; Freedberg and Gallese (2007) for a broad discussion of the relevance of mirror neurons to studies of aesthetic response in art history.

xxvii Settis (1997), Settis (1984).

xxviii Settis (1997); Settis (1984) 197 for anthropological comparanda establishing the cross cultural recurrence of some of the gestures which are then codified by artists into artistic 
formulae; cf. also Gombrich (1982c). For comparative anthropological study of expressive gestures, facial expression, exploring the relationship between universal human tendencies and variant cultural elaborations see Eibl-Eibesfeldt (1989) 425-457.

${ }^{\text {xxix }}$ Lee (1993).

${ }^{x x x}$ Settis (1984) 209.

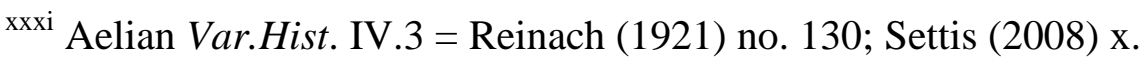

${ }^{\text {xxxii }}$ Radt (1985) TGF III, p. 266 with Settis (1997) 45.

xxxiii Arist. Poetics. 1447a24-5; Settis (2008) ix.

${ }^{\text {xxxiv }}$ Aristotle Metaphysics 985b16, 1042b14: 'rhythmos schema estin', with Kuriyama (1999)

88. The key texts on rhythmos in relation to art, Pollitt (1974) 218-28; schema : ibid. 258-62.

${ }^{x x x v}$ Kuriyama (1999) 81-93, esp. 88-91 and Pollitt (1974) 224-5: rhythmos as the pause bounding movements.

xxxvi Kuriyama (1999) 112-148.

xxxvii Kuriyama (1999) 129-133.

xxxviii Leftwich (1995) 48-9, discussing the Hippocratic texts: Fractures viii.1-6, xxii.8-12.

Note that both of these texts do in fact refer to muscles, $\mu \tilde{v} \varsigma$, notwithstanding Kuriyama's generalisation that analyses of the body tend to emphasise only flesh (sarx) and sinews (neura), within which what we would call 'muscle's tend to be assimilated. xxii.8-12:

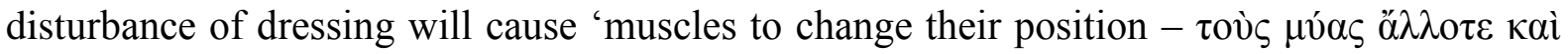

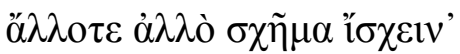

${ }^{x x x i x}$ Xenophon Memorabilia III.x.6-8, translation of Tobin (1995) 57, 56-8 for discussion of the relevant medical texts in the Hippocratic Corpus, esp. On Fractures ii, On Joints 1xii.39ff on correct position (schema) in rest and movement. On Fractures ii analyses the 'schemata' (configurations) of sarx and neura apparent to different activities (throwing the javelin, using a sling, casting a stone, boxing, archery), fitting Kuriyama's model; but cf. On Fractures

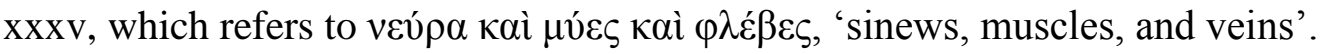

${ }^{\mathrm{xl}}$ Kuriyama (1999), 134-43. Arist. Physiogn. 810a15-31.

${ }^{x l i}$ Kuriyama (1999), 134-43. Arist. Physiogn. 810a15-31.

${ }^{x l i i}$ Metraux (1995) for the most wide-ranging discussion of the evocation of medical semeia of health in fifth century BC Greek art; Simonides 5.19 for hygies aner, bringing benefit to his city (onesipolis) through his sense of justice, discussed Tanner (2006), 127-8.

xliii Plato Laws VII.815a; Tanner (2000) 193-203 on bodily practices; Castriota (1992) 37 for the contrasting characterisations of lapith and centaur. 


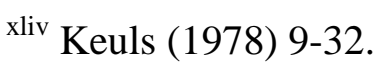

${ }^{x l v}$ Plato, Protagoras 326a, with Keuls (1978) 23-4.

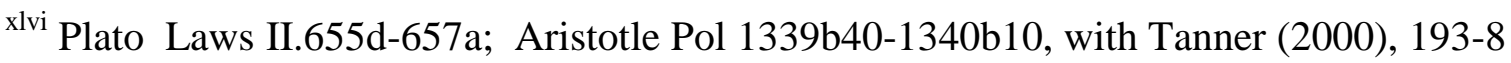

${ }^{x l v i i}$ Aristotle Pol VIII.v.2-4 = 1339b40-1340b10.

xlviii Barron (1972), Castriota (1992) 37-43.

xlix Harrison (1972).

${ }^{1}$ Xen. Mem. III.x, cf. Tanner (2000)199.

${ }^{\text {li } H d t . ~ 6.109 ; ~ H a r r i s o n ~(1972) . ~}$

lii See Hall and Ames (1995)198: 'As one would anticipate, in the classical Confucian context, the relationship between "model" and "image" is appropriately described in a language of correlation between a historically available model and a particular situation, rather than by a subsumption of a particular under a universal category or principle', i.e. as in Greek philosophy in contrast with the correlative character of Chinese thought, as spelled out p. 199 . For the widespread occurrence of such patterns of thought in Athenian rhetoric, see Loraux (1986). This is not to deny, of course, that the elaboration of correlative thought in China was much more extensive than in Greece, simply to indicate that we are operating here not with distinctive incommensurable mentalities, but with cultural systems which draw differentially on human cognitive potentials which are shared, thus rendering the cultures comparable.

liii Cf. Plato Laws II.656; Xen Mem. III.x for the style of viewing.

${ }^{\text {liv }}$ Connor (1972) 159-60.

${ }^{1 v}$ Dem. xlv.17: arbitration of a will.

${ }^{\text {lvi }}$ Ps-Demosthenes lix.94-5: shared courage with the Plataeans at Marathon, and enduring loyalty to benefactors; Aeschines iii.186: admonishing the Athenians on the character of victories, collective, and redounding to the credit of the whole community, not a single individual (absence of Miltiades' name from the painting).

${ }^{\text {lvii }}$ Aristophanes, Lysistrata 630-5, 672-80 (Loeb Translation).

${ }^{\text {lviii }}$ My account of the suturing of diverse semiotic practices in the articulation of novel identities owes much to Sewell's $(2005,337-9)$ account of such processes.

${ }^{\text {lix }}$ Farmer (2000), Farmer (2007) 146, Wu Hung (1989) 287, Fontein and Wu (1976) 10; Murray (2007) 27-36.

${ }^{1 x}$ Murray (2007) 27-36.

${ }^{1 x i}$ Gao Wen (1987) 46-7, Fontein and Wu (1976) 10, Xing (1987) 469-75. 
1xii Wu Hung (1996) 250 - inscription on the An Guo brothers' tomb, and Wang Yanshou's description of the Hall of Spiritual Light in the Lu principality.

lxiii Powers (1991).

${ }^{\text {xxiv }} \operatorname{Lim}(1987) 52$.

${ }^{1 x v}$ Wu Hung (1987) 152; cf. Powers (1987) 61 - with the slightly perverse suggestion that the depiction has no moral content because the figure of the wife is characterised in such an alluring way.

${ }^{\text {lxvi }}$ Lim (1990) 116-9 discussing the Boston tiles.

lxvii Powers (1998) 7-8, Powers (1991) 914.

Ixviii Translation Acker II.58-9, III.70.

${ }^{1 x i x}$ Translation Powers (1991) 914. Cf. Acker II.60, III.70.

1xx Translation Powers (1991) 914; Cf. Acker II.59-60, III.70.

1xxi Translation Bush and Shih (1987) 21.

1xxii Jullien (1995) 27-8.

lxxiii Jullien (1995) 93.

${ }^{\text {lxxiv }}$ Lo (2011), 70-5.

${ }^{\text {lxxv }}$ Lo (2011) 70-1. This is presumably the background to the similar animal analogies which inform later calligraphic texts, and even the fingering for playing the lute: cf. Jullien (1995) 108-116. On animal-human metamorphosis, Stercx (2002), 181-194, p. 190 on Daoyin tu.

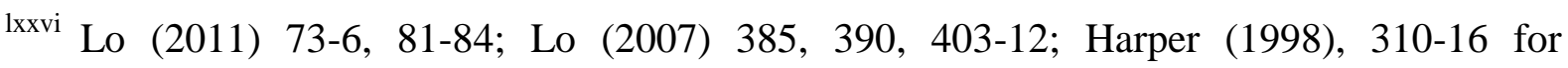
translation of the captions. Tang Lan (1979) 49-52 black and white plates of complete set of figures, 95 for transcription of the captions. For colour plates of a selection of the figures: Zhongguo meishu quanji, Huihua pian vol 1 (1997) 33, 82-5.

lxxvii Lo (2011) 76.

1xxviii Adapting Jullien (1995) 76 on calligraphy 'the force that runs through a character and animates it'.

${ }^{\text {lxxix }}$ Chaves (1968) 8-10, Bulling (1967) 21-2, Chen (1995) 244-6, Chen (2011) 76-80.

${ }^{1 x x x}$ Lim (1990) 108-9: esp. on the 'billowy costumes', suggesting 'wind from within', and discussing the 'calligraphic lines, thickening and thinning', which 'further convey the intensity of a highly charged atmosphere by their fluid, undulating rhythm', though making no reference to the possible connection between these motifs and concepts of $q i$.

lxxxi Cf. Thompson (1999) 15-17, fig. 7: comparing versions of the same story at Luoyang (Henan) and at Yinan and in Songshan (both in Shandong): all of them have the same 
billowing drapery and expressive gesture, i.e. drawing upon a repertoire of physiognomic naturalism which cuts across the distinctive regional and class styles identified by Powers and tells against Powers' claim that these are radically discrepant traditions.

lxxxii Gombrich (1982c) 62, Poffenberger and Barrows (1924).

1xxxiii Lewis (2006) 70, discussing the motif, and its recurrence in narratives of heroic rage in dynastic histories of the Han. Huangdi neijing lingshu jiaozhu yu yi 50 (Shanghai kexue jishu chubanshe 1986, p. 323-4), translated Lewis.

lxxxiv Wang (1994) 531.

${ }^{1 x x x v}$ Zeng Zhaoyu et al(1956) plate 60, bottom panel.

lxxxvi Wang (1994) 531, for the argument, and the examples below.

lxxxvii HHS 81.2665-702; HHS 81.2607; HHS 81.2670, with Wang (1994) 531.

lxxxviii See, for example, Mark Csikszentmihalyi's discussion $(2004,228)$ of the 'Rongjing' chapter of the Xinshu, which defines proper appearance of the face and the eyes, modes of sitting and standing, and styles of speech for four key contexts: in court, at sacrifice, on military service, and in mourning. The development of the enthusiasm for singular deeds, and the air of value, in the late Han, seems to have been an elaboration of characteristics of the disposition and comportment of the warrior, already described in the Book of Rites in the early Han in the following terms: 'The carriage of a warrior was bold and daring; his speech had a tone of decision and command. His face was stern and determined and his eyes were clear and bright' (Li Ji 30.22a; Legge Rites II.26). By contrast, 'The carriage of the man of rank was easy but somewhat slow; grave and reserved when he saw anyone whom he wished to honour. He did not move his feet lightly, nor his hands irreverently... His looks were grave... When at leisure or at ease and in conversation he looked mild and bland' (Li Ji 30.21b Legge Rites II.25), perhaps exemplified by the figures from the Boston Tiles, (figure 2) - Powers (1991) 64-5. In both cases a contextually appropriate accumulation, regulation and dispersal of $q i$ is entailed.

lxxxix Yates (1994) 70-1.

${ }^{x c}$ Sivin (1995) 20-5, on political and cosmic harmony as entailing the free flow of $q i$ between heaven, the ruler and his subjects, and the role of 'heroic retainers and faithful ministers', to break through or release any blockage in the free-flow of qi through appropriate advice or action to rectify such stasis; Yates (1994), p. 68, particularly clear on the medical analogy: disease of the body caused by blockages of qi flowing through the vessels of the body, 
comparable with its flowing through emperor, ministers etc. as earthly conduits in harmonious regulation of social and political relations.

${ }^{\text {xci }}$ Acker I.73-5. Cf. He Pingshu's 'Rhapsody on the Hall of Great Blessings', built by Ming, an emperor of the Wei dynasty, ca $230 \mathrm{AD}$, so very shortly after the Han with which this article is primarily concerned, but indicative of the general orientation nevertheless: 'By viewing the comportment of Lady $\mathrm{Yu}$, they understand how a fawning minister governs a state..[], They deem worthy the forthright words of Zhongli, /Admire the self-abnegation of Lady Fan,/ Extol Lady Ban for declining the cart' etc. - translated Knechtges (1987), 291-3. ${ }^{x c i i}$ Circa 17-15 BC, an official, Liu Xiang, scandalised by the emperor Cheng's relationships with two overambitious concubines, made a collection of biographies of good and wicked women, which was produced first as an illustrated scroll, and then on a larger scale as a fourpanelled room-screen: HS30.1727, Barbieri Low (2007) 163, Wu Hung (1989) 170-1, Murray (2007) 28. At the behest of the emperor Ming, two scholar-officials, Ban Gu and Jia Kui, were ordered to make a selection of stories from the Classics which were realised as wall-paintings for the palace by painters from the Shangfang, the Directorate of Imperial Manufactories (Barbieri-Low 2007, 196-7).

${ }^{x c i i i}$ Wang Wenkao, Rhapsody on the Hall of Numinous Brilliance (靈光殿), constructed by the Han King Liu Yu, King Gong of Lu (reigned 154-129/8 BC), but still used by Lu kings in the Eastern Han; date of Wang Wenkao ca. 124-ca 148: Bush and Shih p. 25 for an extract; translated in full Knechtges (1987) 263-278, lines 138-67 (p. 273-5) on the paintings; He Pingshu, Rhapsody on the Hall of Great Blessings (景福殿), built first half third century AD by the Wei Emperor Wang in the city Xuchang, Henan Province - translated Knechtges (1987) 279-304, vii.192-219, p.291-3 for the narrative paintings.

${ }^{\text {xciv }}$ Wang Wenkao - Knechtges (1987) 275, lines 166-7: 'The wicked are warnings to the world,/ The good are examples for posterity'); He Pingshu - Knechtges (1987) 291, lines 196-9: 'They paint forms from the ancient past/ To serve as warning and monition./ For ladies of the pepper rooms, / These are examples, these are models.', 293, line 218 'day viewing, night perusing'.

${ }^{\text {xcv }}$ Han Shu (HS) 97.3983-4; translation Watson (1974) 261-2. Some years later, driven to retirement from the court by the slanders of other concubines, Lady Ban wrote a $f u$ or prosepoem in which she describes how, in her solitude, she 'spread out paintings of women, made them my moral mirror (陳女圖以鏡監 - lit: a mirror for examining oneself)', giving herself instruction through contemplating the stories of the good and the wicked women of Chinese 
history (HS 97.3985, trans. Watson (1974) 263 adapted); Barbieri-Low (2007) 163. Again, the vocabulary of Lady Ban's Fu is telling for the character of the Han institution of art, fusing as it does moral and aesthetic vocabulary and using terms equally applicable to the work, and the actions it depicts.

${ }^{x c v i}$ McCausland (2003) plates 1-13 for the Admonitions Scroll, 14-19 for the fifth century screen from the tomb of Sima Jinlong.

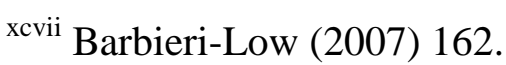

${ }^{x c v i i i}$ HS 66.2890-1, with Barbieri-Low (2007) 162, Wu Hung (1989) 164, Acker I.112.

${ }^{\text {xcix }}$ HS 68.2932, translated Watson (1974) 123.

${ }^{c}$ Wu Hung (1989) 224.

${ }^{c i}$ Wu Hung (1989) 287, citing Sui Shu 1676.

${ }^{\text {cii }}$ For an illustration of the strongman: Portal (2008), fig. 160, Cat. No. 114.

ciii Shandongsheng wenwu kaogu yanjiu suo (2010) colour Plate 2, cf. colour plate 5.

${ }^{\text {civ }}$ Pollitt (1972) 115-125.

${ }^{\mathrm{cv}}$ I do not mean to altogether rule out cultural interactions of these kinds as having played some role in the development of figurative representation in early imperial Chinese art, though I think they have limited added explanatory value in relation to the broader socialpolitical explanations I have been advancing, and this is particularly clearly brought out by comparative analysis, where we are able to explain both the parallels and the differences between Greek and Chinese 'naturalism' within a unified theoretical framework. In so far as external influences were sources of inspiration or stimulus for the development of figurative imagery (Weber, Jacobson) or its style (Rostovtzeff, Nickel) we can only explain the taking up of such 'influences' and the extent or limitations of their longer term impact in terms of the institutional frameworks into which they were appropriated in China, which brings us back to the broadly sociological approach I have been advocating. In considering the specific issue of narrative and naturalism in the Han, the receptivity of the Han to such putative 'influences' could only be explained by the social conditions, and the specifically Chinese inflection of those received influences by the indigenous Chinese cultural traditions which I have explored. It seems simpler to see the Chinese development as effectively a largely independent one.

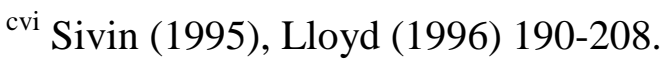


PLATE LIST

\section{CAPTIONS - NARRATIVE AND NATURALISM}

(See attached folder for permission documents. Figures 17 a are author's own. Figures $\mathbf{6 a}, \mathbf{8}, \mathbf{1 0}, \mathbf{1 4}$, 15a, 17b, 18, 20a-b, 22 are non-copyright/public domain)

Figure 1. Drawing from figurative decoration of Bronze Hu vessel, depicting scenes of ritual and warfare. Warring States. Ht of Vessel: $39.9 \mathrm{~cm}$. Sichuan Provincial Museum. Photo: Wenwu Chubanshe.

Figure 2: Detail from painted tile lintel of a Western Han Tomb, Luoyang, middle first century BC. Gray earthenware hollow tiles with coloured pigments. Gift of C.T. Loo 25.190. Meeting of Confucius and Laozi (?). Photograph (CBoston Museum of Fine Arts.

Figure 3: Attic Geometric krater, late $8^{\text {th }}$ century BC. Laying out of the deceased and funerary procession. Image copyright The Metropolitan Museum of Art/Art Resource/Scala, Florence. Photo@ 2015 SCALA, Florence.

Figure 4: Attic red figure vase by the Brygos painter, ca 470-460 BC. Encounter of Sappho and Alcaeus. Munich, Antikensammlung. Image: Staatliche Antikensammlung und Glyptothek, München; photograph by Renate Kühling.

Figure 5: Rubbing from Front Chamber, Wu Liang Shrine: Min Zi Qian's Filial Piety. Mid- $2^{\text {nd }}$ Century AD. Source: E. Chavannes (1913), Mission Archéologique dans la Chine sepentrionale vol 2, pl. 49, no 104. Photo: Bodleian Library, Oxford.

Figure 6a: Assembly before Marathon? Vase-painting by the Niobid Painter, ca 460 BC. Drawing from A. Furtwängler and K. Reichold. Griechische Vasenmalerei (Munich 1900); 6b: Reconstruction drawing by K. Jeppesen, marking gaze directions. From Acta Archaeologica XLI (1970).

Figure 7: Herakles and Apollo contest the Delphic Tripod. Amphora by the Andokides Painter, ca 525 BC. Berlin, Staatliche Museen, F2159. Photo: Hirmer Verlag.

Figure 8. Sack of Troy. Hydria by the Kleophrades Painter, ca 490-80. Naples, National Museum 2422. Drawing from A. Furtwängler and K. Reichold. Griechische Vasenmalerei (Munich 1900-1932).

Figure 9: Peleus and Thetis. Attic red-figure vase. Vatican. Mid- $5^{\text {th }}$ Century BC. Photo: Vatican Museum.

Figure 10: Penelope at her loom. Skyphos by the Penelope Painter ca 440 BC. Drawing From A. Furtwängler and K. Reichhold, Griechische Vasenmalerei (Munich 1900-1932).

Figure 11: Pensive Bodhisattva, Northern Wei, early sixth century. Originally from Guyang Cave, Luoyang. Source: Jan van Alphen ed. The Buddha in the Dragon Gate. Etnographisch Museum, Antwerp.2001. Photo: Willy de Lauwer.

Figure 12: Polykleitos, Doryphoros, ca 440 BC. Roman marble copy of Greek bronze statue. Photo: Anderson; Alinari Archive, Florence. 
Figure 13: Kritios and Nesiotes, The Tyrannicides, 477/6 BC. Roman marble copy of fifth centuty Greek bronze statues. Museo Nazionale, Naples. Photo: Museum. By permission of Ministero dei beni e delle Attività Culturali e del Turismo Soprintendenza dei Beni Archeologici di Napoli.

Figure 14: Attic red-figure krater, by the Florence Painter. Centauromachy. Ca 450 BC. (Florence, Archaeological Museum 3997) Source: E. Pfuhl (1923), Malerei und Zeichnung der Griechen. Munich. Fig. 28.

Figure 15a-b: Volute Krater by the Painter of the Woolly Satyrs, ca 460 BC. NY Metropolitan Museum of Art 07.286.84. a) Drawing from Furtwangler, A. and Reichhold, K. Griechische Vasenmalerei Munich: Bruckmann; 1924, pl. 12. b) Image copyright The Metropolitan Museum of Art/Art Resource/Scala, Florence. Photo@ 2015 SCALA, Florence.

Figure 16: Athena Nike Temple, South Frieze, ca 420 BC. Detail. Photo @ Trustees of the British Museum.

Figure 17a-b: Stone sarcophagus relief, from Xinjin County, Sichuan. Eastern Han (AD 25-220); 74.5 x $213 \mathrm{~cm}$. Detail (rubbing): Qiu Hu and his wife. Sichuan University Museum. Sources: a) Photo: Jeremy Tanner b) Sichuan Handai Huaxiang Xuanji 1957, fig. 40.

Figure 18: rubbing from Yinan Tomb engravings, Zhang Liang and Fan Zeng; $2^{\text {nd }}$ century AD. Source: Zang Zhaoyu, Jiang Baogeng and Li Zhongyi. 1956. Yinan guhua xiangshimu fajue baogao, pl. 56.

Figure 19: Daoyin tu (導引圖) or “Guiding and Pulling Chart", Silk Manuscript from Mawangdui. Western/Former Han. Early $2^{\text {nd }}$ century BC. Detail. Bottom centre: "Monkey bawling to pull internal hotness". Photo: Wenwu Chubanshe.

Figure 20a-b: Painted terracotta tomb gable from Luoyang, Henan, late $1^{\text {st }}$ century BC. Drawing from frieze: Two Peaches Kill Three Warriors. Source: Kaogu Xuebao 1964.2.

Figure 21: Han Mirror with the story of Wi Zuxu. Photograph and rubbing. Bottom: death of Wu Zixu. Lower Yangzi River, Shanghai Museum. Shanghai bowuguancang qingtongqi, Shanghai, 1964. II pl. 95. Photo: Cambridge University Library Imaging Services.

Figure 22: Rubbing from Yinan tomb engravings, unidentified narrative. Second century AD. Source: Zang Zhaoyu, Jiang Baogeng and Li Zhongyi. 1956. Yinan guhua xiangshimu fajue baogao. Plate 59.

Figure 23: Story of Bo Yu. Wu Liang Shrine, $2^{\text {nd }}$ Century AD. Detail from rubbing of the Front Front Source: E. Chavannes (1913), Mission Archéologique dans la Chine sepentrionale, vol 2, pl. 49, no 104. Photo: Bodleian Library, Oxford.

Figure 24: Wooden figure from fourth century BC Chu tomb. John Hadley Cox Archaeological Study Collection, Freer Gallery of Art and Arthur M. Sackler Gallery Archives, Gift of John Hadley Cox, 1991. Photographer: John Hadley Cox 11.1.

Figure 25: Warrior, from Han Tomb M1 Houtun, Shandong. Eastern Han. Source: Shandong sheng wenwu kaogu yanjiu suo 2010, plate 3. Photo: Wenwu Chubanshe. 
Figure 26: Detail from hydria by the Meidias painter, Rape of the Leuccipides. Late fifth Century. British Museum. Photo: Hirmer Verlag. 